DOI: 10.19195/0137-1150.167.36

\author{
NATALIA MALUTINA
}

Uniwersytet Rzeszowski, Polska

Одесский национальный университет им. И. Мечникова, Ukraina

\title{
Смерть в симулятивном пространстве гиперреальности современной русской драмы (на примере пьес Олега Богаева)
}

Тему трансгрессии жизни и смерти можно считать одной из наиболее популярных в игровом пространстве той постмодерной русской драмы, к которой, с большими или меньшими оговорками, можно отнести понятие

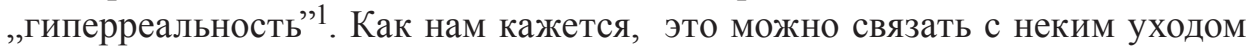
драматургов (особенно это проявляется их творчестве конца 80-х-90-х годов XX века) в область виртуального, абсурдного, с одной стороны, и стремлением довести до гротеска, обнаружить деструкцию в явлениях действительности, с другой.

Такой вектор, очевидно, был связан с укрепившимся в то время определенным недоверием к репрезентации действительности, непременно несущей в себе идеологический диктат интерпретации.

Для многих авторов пьес важно было отозваться на злободневные проблемы путем перенесения в сферу симулятивных игровых манипуляций, которые привлекали к себе не меньшее внимание зрителя, чем «вечные вопросы».

Богатый ассоциативный ряд значений, вызываемых концептом „смерть”, позволял драматургам передать ироническое отношение к явлениям и процессам культурной трансгрессии. К тому же со многих тем были сняты к этому времени табу, так что уже нередко в заголовке пьес можно было встретить слова „смерть” („мертвый”). Среди них, например, монопьесы Вадима Леванова Смерть Фирса (1998), Ты будешь лежать одинокий и мертвый (2002),

1 Это понятие применительно к постмодерной русской литературе разработал Марк Липовецкий. См.: М. Липовецкий, Паралогии. Трансформации (пост)модернистского дискурса в русской культуре 1920-2000 годов, Москва 2008. 
пьеса Михаила Угарова Смерть Ильи Ильича (2000), пьеса-сценка Олега Михайлова Мои мертвецьы (1991), Алексея Шипенко Смерть Ван Халена (1989), Ирины Васьковской Русская смерть или Где Надя, которая пошла за водкой (2013).

Образ-симулякр смерти появляется в пьесах екатеринбургского драматурга, ученика Николая Коляды, Олега Богаева как постоянное немотивированное повторение в высказывании штампов, стереотипов речи, направленных на самих себя, и как ироническая попытка выразить недоверие к разным процедурам репрезентации действительности, закрепляющим принятые в культуре принципы, ритуалы, жесты, высказывания в ходе интерпретации того или иного явления. Почти во всех пьесах О. Богаева так или иначе присутствует симулякр смерти. Он же распознается в названии комедии Мертвые уши, или Новейшая история туалетной бумаги (1998), хотя во всех остальных также становится главным способом высказывания, обуславливающим общение с персонажами.

Отметим, что анализ текстов пьес осуществляется по книге О. Богаева Русская народная почта: 13 комедий, изданной в 2012 году в Екатеринбурге $^{2}$. Это тем более важно, что большинство пьес существует в нескольких редакциях, зачастую существенно отличающихся друг от друга ${ }^{3}$.

Не случайно, по-видимому, все эти пьесы названы автором комедиями. Смерть традиционно была героем народных комедий, фарсов, вертепа, потешных действ и т. п.

Кроме того, встреча со смертью во многих комедиях О. Богаева вызывает эффект комически иронического гипертрофированного повторения, дублирования, воображаемых ситуаций, часто разыгрываемых в сознании персонажа (Сансара, 2006; Шпильки, 2012) или нарратора (Русская народная почта, 1998; Страшный суn, 2012), сводимых, как нам кажется, к одному явлению (идее) превращения культурных смыслов в симулякры.

В пространстве пьес О. Богаева стираются границы между реальным и воображаемым представлением о смерти, точнее, о переходе жизни в смерть и наоборот. Условная реальность переходит в ранг гиперреальности, следуя мысли Жана Бодрийяра. Образ переживания смерти или, возможно, говорения про смерть функционирует в поэтике указанных комедий как симулякр, что, безусловно, разрушает привычное представление о смерти. Вспомним, что, по мысли Ж. Бодрийяра, образ смерти существует

2 О. Богаев, Русская народная почта: 13 комедий, сост. В. Э. Исхаков, Екатеринбург 2012, http://bogaev.narod.ru [дата обращения: 11.08.2017]. Далее цитируем тексты по этому изданию.

3 Так, пьесы: Русская народная почта, Мертвые уши, или Новейшая история туалетной бумаги, впервые вышли в издании Арабески: сборник пьес уральских авторов, Екатеринбург 1998. 
как миф, поскольку для осознания своей идентичности субъекту необходим миф о его конце, так же как и миф о начале 4.

Более того, отстроченная смерть (или, как часто это встречается в современной драме, театрализованная жизнесмерть) становится симулякром, модусом призрачного существования, которое, используя метафору Ж. Бодрийяра, можно сравнить с вампирическим паразитированием мифа на теле первичного языка.

Рассмотрим, благодаря каким художественным средствам в поэтике пьес О. Богаева, в речи персонажей и нарратора формируется симулятивное представление об иллюзорности смерти, переходе жизни в смерть, и/или, наоборот, отделении факта (явления) смерти от сознания индивида их условном дистанцировании.

В ходе анализа возьмем на вооружение некоторые положения из работ Жиля Делеза (Пять тезисов о психоанализе и $О$ смерти человека и о сверхчеловеке $)^{5}$ и из уже упоминаемых книг Ж. Бодрийяра.

В то же время, говоря о безусловном влиянии психоанализа на процессы мировой культуры, Ж. Делез отмечал его авторитарность, использование ,автоматической машины интерпретации”6.

В частности, как подчеркивает философ, что бы не говорили, говоримое нами слагается из двух сфер: субъекта высказывания и плана субъекта акта высказывания ${ }^{7}$. Применительно к поэтике драмы такое расщепление субъекта высказывания позволяет понять механизм создания и действия симулятивного представления, стереотипа сознания, речевого штампа, расхожего, закрепленного сознанием шаблона.

В пьесе Русская народная почта Иван Сидорович Жуков (чеховский персонаж, перенесенный в реалии нашего времени) сообщает в большой вступительной ремарке о том, что он уже три года ведет призрачное существование (доживания), игнорируя факт смерти жены (,[...] факт смерти жены был сам по себе, отдельно от него, был чем-то вроде трещины на потолке, которая сама по себе, а Иван Сидорович сам по себе") ${ }^{8}$.

Если это утверждение можно соотнести с поведением и высказыванием персонажа, то ироническая фраза о том, что герой был философом и почитал Платона (в частности, его мысль: „Жизнь есть постоянное движение от рождения к смерти"), напоминает попытку авторского симулирования смыслами. Ироническое сравнение персонажа с Платоном весьма показа-

4 Эта мысль неоднократно встречается в работе Жана Бодрийяра: Ж. Бодрийяр, Cuмволический обмен и смерть, пер. С. Зенкин, Москва 2000.

5 Ж. Делез, Пять тезисов о психоанализе, пер. Н. Архипов, Москва 2010; его же, О смерти человека и о сверхчеловеке, пер. Н. Архипов, http://www.twirpx.com/file/1890180/ [дата обращения: 3.09.2017].

6 Там же.

7 Там же.

${ }^{8}$ О. Богаев, Русская народная.... 
тельно, ведь, как убедительно показано в работе Ж. Бодрийяра Символический обмен и смерть, понятием симулякра, по сути, оперирует в своей теологической концепции репрезантации Платон.

Таким образом, упоминание нарратором в ремарке философских идей Платона задает модус иронической рефлексии по отношению к самому механизму создания симулякров, их функционирования, их вовлеченности во всеобщую игру смыслами.

Видимость реального сохраняется в пьесе во всем: Иван Сидорович сам пишет себе письма и отвечает на них, его корреспондентами становятся Королева Елизавета II, Ленин, актриса Орлова, Сталин, российский президент, марсиане, клопы и, в конце концов, Смерть.

Чтение письма от Смерти становится кульминацией дня рождения Ивана Сидоровича, возникает фантасмагорическая театрализация полного разрушения страха смерти, ожидания ее прихода: смерть утрачивает характеристики мифологического существа, забирающего человека на тот свет. В этом письме смерть пишет о себе с маленькой буквы. Она больше, чем кто-либо заботится о герое, поздравляет его и дарит в подарок обещание вечной жизни.

Такая трансформация привычного представления о смерти разрушает план условного правдоподобия и демонстрирует „ускользание” от общепринятой логики.

Иван Сидорович озадачен, не знает, верить или нет письму, в его сознании звучат слова: „Вечно. Вечно [...]”, никак не согласуясь с суетной жизнью рядом (стучат по батарее, трубит горн, встречают Новый год...).

Осуществленный Иваном Сидоровичем уход в сторону симулятивной жизни, замещения действительности фантомами заставляет нас (зрителей) усомниться в его присутствии в качестве персоны на сцене. Можно думать об имплозии ${ }^{10}$ (втягивании его присутствия) в качестве „я” в виртуальное пространство слов, может быть, обломков смыслов и значений, что, вероятно, увлекает вслед за собой реципиента. В связи с этим нарушается привычный режим коммуникации между зрителем и актерами, читателем и его восприятием образов-симулякров. Реципиент концентрирует внимание на нестабильностях, на моментах переключений, в которых неожиданно возникает иной тип восприятия, связанный с эстетикой абсурда.

Такая деконструкция смыслов может показаться провокационной, тем более что личность персонажа Ваньки Жукова очень далеко отошедшего от чеховского прототипа, уходит на задний план, она скрывается за высказыванием симулякров-адресатов писем. В их странных репликах переплетаются стереотипы постсоветских установок, взглядов (например, из

9 О. Богаев, Русская народная...

10 См. об этом раб. Ж. Бодрийяра Пароли. От фрагмента к фрагменту, пер. Н. Суслов, Екатеринбург 2016, http://baudrillard.paroli-2006-81.pdf [дата обращения: 3.09.2017]. 
письма Мишки, Гришки и Федора следует: „Жизнь наша как в сказке. У нас выросли в большом количестве дети. И все хорошие, умные [...] Город наш красивый, о каком и мечтать только можно [...]"11) с современным бытовым мышлением обычного человека (Елизавета II и Ленин готовы драться в расчете получить квартиру героя после его смерти). Для этих одушевленных образов-симулякров Смерть - уже состоявшийся факт, поэтому они зачитывают, кому что завещано покойным. Можно отметить, что в речи персонажей лишь симулируется присутствие смыслов, логики. Таким образом, язык симулирует наличие дискурса.

В таком представлении переход персонажа от жизни к смерти, осуществляемый по законам игры, симуляции, напоминает о фантомном существовании вечного Ваньки Жукова (он живет как некий штамп сознания, продукт коллективной утопии), совершенно отделившись от литературного персонажа. Его можно условно назвать симулякром „вечного (не) возвращения". Конечно, подобное восприятие во многом отражает взгляды, жизненный опыт самого уральского драматурга.

Однажды в интервью, опубликованном в журнале „Современная драматургия”, О. Богаеву был задан вопрос о том, как он относится к главной теме в своих пьесах — теме смерти? Последовал следующий ответ:

- Все просто: смерть - главный персонаж, финал, занавес, да тут масса синонимов, которых не перебрать. Мысли, рассуждения, фантазии и философствования человека о смерти - этот обязательный набор более-менее задумывающегося человека, но все это тщетно, смерть - главный герой, она несет ту функцию осветителя, когда свет выключается, и - конец спектакля. Все что бы сейчас ни сказал о смерти - все сказано тысячу раз и совсем выглядит иначе и непостижимей, когда это касается самых близких.

Пьеса - модель жизни, отрезок бесконечности, надо ясно понимать драматургу, что жизнь идет непрерывным потоком до пьесы и после, мы выхватываем только каплю воды из падающего океана и делаем ее абсолютом на полтора-два часа? ${ }^{12}$

О. Богаев отметил, что гениальный драматург ,,реконструирует” время в пьесе. В пьесе главное - время, его движение, подлинность. Можно принять за исходный пункт анализа мысль о том, что драматург осознает ограничения репрезентации действительности, снабженной навязанными культурой, образованием, опытом, значениями, интерпретациями. В то же время, не стоит утверждать, что О. Богаев воспринимает мир только как игру симулякров, создающую подобие реальности, в которую, в равной степени, включены все мы, он и его персонажи. Подобный уклон в гиперреальность становится для него, как нам кажется, также объектом комически иронического наблюдения.

${ }^{11}$ О. Богаев, Русская народная....

12 О. Богаев, Пьеса - это модель жизни, отрезок бесконечности, беседу ведёт Светлана Новикова, „Современная драматургия” 2013, № 4, с. 189. 
Можно несколько развить наблюдения Светланы Васильевой над тем, что герои Богаева живут вне времени, смерть становится синтезатором всех видов времени, тем самым она избавляет персонажей от реальности жизни, дарует иное загадочное измерение жизнесмерти ${ }^{13}$.

Вспомним, что, по мнению Ж. Бодрийяра, сама экзистенциальная ситуация современного человека искажена, вовлечена в парадоксальную симулятивную темпоральность, борьба со смертью ведет к переходу смерти непосредственно в жизнь, ставшую на практике уже симулякром жизни ${ }^{14}$.

Фантасмогорическая и абсурдно-трагикомическая повторяемость перехода от жизни к смерти (и наоборот) организует действие в таких пьесах О. Богаева как Сансара, Страшный суп. Продолжение преследует в двух актах, Тайное общество велосипедистов, Шпильки, Мертвые уши, или новейшая история туалетной бумаги.

Каждая из этих комедий представляет некую авторскую идею, некий опыт преодоления привычной логики посредством разных поэтикальных форм деконструкции. Название поэмы Николая Гоголя Мертвые души в результате случайной деформации восприятия (кто-то надорвал страничку Н. М.) изменилось в Мертвые уши, а апокалиптический смысл Страшного суда трансформировался по воле случая в Страшный суп. Продолжение преследует в 2-х актах (ред. 2012 года).

В обеих пьесах повторяется ситуация „заклинивания”. Нелепая опечатка (вместо страшный суд в Библии напечатано суп) влечет за собой регламентацию определенной модели мировосприятия, поведения, образцов репрезентации, а это создает представление о всеобщем абсурде, из которого, кажется, нет выхода.

Вследствие зацикленности времени, обозначенного абсурдным сдвигом логики как День Страшного Супа, симулятивно повторяется одна и та же ситуация: сосед молодоженов Глаши и Феди, Кондрат Филлипович на их глазах разбивается на своем мотоцикле, но тут же вновь и вновь появляется перед дверью их квартиры, с теми же самыми словами об экспедиции, поезде и т. д. Подобно заеданию старой пластинки, персонаж попал в ловушку времени, которое проделывает вхолостую оборот за оборотом, при этом выбраться из этого, кажется, невозможно.

В речи наблюдающих за происходящим Глаши и Феди проявляется невозможность изменить события, равно как не удается окончательно убить соседа.

Федя (с досадой). Ой, да не болтай ерунды, Глаша!... Как я мог его убить, если он уже был... Мертвый.

13 С. Васильева, Пьесы Олега Богаева и проблемы современного драматургического языка, „Вестник Волгоградского государственного университета” 2013, сер. 8, вып. 12, „Литературоведение. Журналистика”, https://cyberleninka.ru/article/n/piesy-olega-bogaeva-iproblemy-sovremennogo-dramaturgicheskogo-yazyka [дата обращения: 12.08.2017].

14 Ж. Бодрийяр, Символический обмен и смерть.... 
Федя. Ну да, один продолжает мылить себя в бане, другой — щурится с теликом, третий рожает, четвертый — все умирает. Один беспрерывно чихает, другой — ногой качает, пятый - все спит, шестой себя материт ${ }^{15}$.

В определенном смысле действие пьесы иллюстрирует вступительную ремарку к пьесе, в которой содержится рассуждение о симулятивном застревании во времени.

Человек всегда мечтал убежать от времени, ускакать от смерти на четвереньках. Человек всегда мечтал жить вечно, по крайней мере, жить больше, чем сосед с верхней лестничной клетки. И что же теперь, когда время остановилось? Кто отмерит наши грехи, кто заставит нас заглянуть в зеркало, когда ты вечно грудной ребенок, когда тебе вечно или восемнадцать или сорок или шестьдесят лет? Когда нет ни будущего, ни прошлого, а есть призрак... Мираж настоящего?

Еще по инерции стучат часы, по инерции мы ищем на циферблате ложку стрелок. Но увы!.. Скоро завод кончится, и нам придется признаться в том, что мы попали в идиотское положение - нет смерти, нет судьбы, нет ничего, кроме рокового анекдота о том, как человек мечтал о нескончаемой тарелке супа, и вот, она перед ним. Он ест, ест, ест, а суп никак не кончается! ${ }^{16}$

Такое смещение образов в сторону случайного, бессмысленного порождает символические смыслы, возникающие в поэтике высказывания как симулякры, наделенные межличностными характеристиками.

Так, в поэтике пьесы не формируется индивидуальный опыт смерти Кондратия Филипповича, он вообще об этом не помнит и не думает. Его соседи также не воспринимают его много раз повторяющуюся смерть как нечто свершившееся, напротив, они более всего озабочены тем, как бы его окончательно убить.

Игра симулякров осуществляется в речи персонажей, которая утратила признаки индивидуального опыта человека. Полностью разрушается система референции и репрезентации: слова ничего не означают и ни к чему не отсылают, кроме самих себя. Путем повторения одних и тех же фраз создается семантическая гиперреальность, в которой язык как бы не имеет обозначаемого („Предмет не называется, а делается намек на название”) ${ }^{17}$.

Реплики Кондрата Филипповича давно утратили смысл, причем некоторые фразеологизмы, привычные устойчивые сочетания только в нашем сознании связываются с семантикой смерти, что никак не сочетается с контекстом. Напротив, языковые несоответствия порождают алогизм абсурда. Приведем несколько примеров:

15 О. Богаев, Русская народная...

16 Там же.

17 Об этом, опираясь на позиции Жака Деррида, пишет, в частности, Елена Пархоменко. См. Е. Пархоменко, Современный язык как симулякр „Дома бытия”, „Историческая и социально-образовательная мысль” 2013, № 5 (21), с. 320, https://cyberleninka.ru/article/n/ sovremennyy-yazyk-kak-simulyakr-doma-bytiya [дата обращения: 18.08.17]. 
К.Ф. ...у вас такие кислые лица, будто кто-то дуба дал...

...Знаете, у Энштейна была шутливая теория, по которой конец света - это не черти с рогами, а зацикленность времени. Если так, то Страшный Суд идет давно, нас всех уже покрошили, посолили и варят. Но мы это не знаем и булькаем в соусе глупости, хотя давно кипим на медленном огоньке ${ }^{18}$.

Заметим, что из-за опечатки Страшный Суд - Суп утрачивается связь с сакральным текстом, а такие фразеологизмы как ,дать дуба”, „кипеть на медленном огне”, „конец света” и др. в определенном контексте вызывают иллюзию коммуникации. На самом деле речь персонажей О. Богаева лишена каких бы то ни было признаков индивидуализации, вместо этого пространство текста наполняется ни к чему не отсылающими конструктами, указывающими на себя, а, значит, удваивающими силу этого указывания.

Речь персонажей наполнена идиомами, обозначающими, но не называющими смерть.

Федя. Значит, мотоциклист все-таки умер?

Глаша. Да, крякнул.

Федя. Тогда объясни, когда он сюда вернулся — если он вдребезги разбился?! 19

Само слово „умирать” утрачивает какую бы то ни было реальную основу, от известного явления осталось одно слово, которое ровным счетом ничего не означает, как уже отмечалось, язык или речь персонажей лишь симулируют дискурс.

Федя. Ну да, один продолжает мылить себя в бане, другой - щурится в телескоп, третий рожает, четвертый - все умирает ${ }^{20}$.

Важно отметить и то, что в процессе серийной репродукции языковых симулякров объектами манипуляции становятся китчевые клише, стереотипы, псевдовещи, ритуалы, жесты. Они подвергаются трансгрессии вследствие иронического тиражирования и обессмысливания. Вспомним, что Мишель Фуко рассматривал трансгрессию как модель перехода к новому языку.

Тема симуляции смерти как трансгрессии воображаемого, выразительно представлена в комедии О. Богаева Мертвые уши или новейшая история туалетной бумаги (ред. 2011 г.). Пьесе предпослан эпиграф из статьи Николая Гоголя В литературном мире нет смерти, и мертвець так же вмешиваются в дела наши и действуют вместе с нами, как живые.

В квартире Эры Николаевны физически крепкой, но не очень развитой духовно и интеллектуально поселяются ожившие классики русской литературы: Чехов, Толстой, Гоголь, Пушкин. Они упрашивают ее взять хотя

\footnotetext{
18 О. Богаев, Русская народная...

19 Там же.

20 Там же.
} 
бы одну книгу в библиотеке, которая закрывается, а, значит, „бессмертные писатели" остаются без крова.

Все они наделены вполне личностными человеческими характеристиками (готовы помогать по хозяйству), имеют свои вкусовые предпочтения и без конца едят. По мере исчерпания запасов еды обогащенная культурным опытом Эра Михайловна обращается в форме стихотворного послания (стилизация письма Татьяны из Евгения Онегина) к соседям с просьбой о помощи в пропитании классиков. Ее беспокоит больше всего, что они умрут с голоду. Такое фарсовое дублирование смерти-бессмертия обнаруживает гиперреалистичность симуляции. Время и история литературы также включаются в систему симулякров, причем они становятся категорией субъективного опыта в фантазматических трансформациях, смещениях, т. е. в ситуации трансгрессии.

То, что на самом деле омертвляется в поэтике высказывания комедии, - это цитаты из книг классиков, попавшие в чуждый им, случайный контекст. В созданной по модели трейлера сцене бандитской расправы с книгами проявляется попытка метонимического переноса признаков живых существ на горящие книги.

В пламени скачет медный всадник, шинель размахивает пустыми рукавами, детство-отрочество-юность стоят, прижавшись друг к другу, горящая чайка бьется в окно 21.

В символической гротескной картине 13 -й вторично умершие в сгоревших книгах классики вновь покидают грешную землю, произнося жизнеутверждающие фразы, давно ставшие бессмертными.

Чехов. Жизнь-то прошла, словно и не жил...

Толстой. Любить - значит жить.

Гоголь. Какое горе не уносит время (Пауза) ... Кто что ни говори, а подобные происшествия бывают на свете, редко, но бывают.

Пушкину для вечности достаточно сказать одно слово.

Пушкин. Пора ... Пора! ${ }^{22}$

Ироническое остранение идеи „вечного невозвращения”, ироническое переворачивание до абсурда симулятивного представления о реинкарнации душ можно проследить в одноактной комедии Сансара.

Действие разворачивается как физическая борьба некой Старухи, защищающей свой уклад жизни, быт, свой мир, и пришедшей к ней женщины, которая поверила в то, что душа ее умершего сына Юры переселилась в тело „котика с белым ушком”. Неприятие рассказанного старухой факта о том, что она накануне утопила всех котят, вызывает сдвиг восприятия персонажей в сферу симуляции, даже манипуляции симулятивными смыслами.
21 Там же.
22 Там же. 
Старуха в угоду почти сумасшедшей матери делает вид, что подыгрывает ей, тем самым пытается нейтрализовать поток ее речи-сознания. Ей удается это сделать буквально, оглушив гостью стулом по голове.

Фантомы реинкарнации в речи Клавдии Строгиной, бывшего члена партии, дополняются симулякрами из другой псевдореальности постсоветского пространства. Оказывается, что обе семантические сферы взаимодополняют одна другую, что порождает иронию.

Старуха. От меня, шпана казанская, один путь - ворота колонии строжайшего режима! И вперед с песнями про кондуктора!.. ${ }^{23}$

Показательна в этом контексте следуюшая за репликой ремарка:

Старуха привязывает безучастную женщину к стулу, достает из шкафа свои медали, прикрепляет себе на грудь. Достает ученическую тетрадку, надевает очки ${ }^{24}$.

Записанные Старухой показания также являются обрывками (или следами) языковых и культурных смыслов, превратившихся в симулякры.

Женщина (не понимает, читает). „Я, Вера Петровна Холодная, диверсант из Космоса, член космического разума, признаюсь в том, что являюсь тайным агентом китайской Кришны, а также организатором антисоветской группы вредителей на фабрике детского питания..."25.

Неожиданно обрушившийся на Старуху шифоньер используется драматургом в качестве игровой симулятивной мотивации переворота в ее сознании. Внезапное потрясение вызвало у нее иллюзию смерти.

Значит, думаю, сыграла в ящик... Лежу и ругаю себя - как же ты, старая, померла и даже не заметила? Лежу, привыкаю к месту, жду, когда явится небесный бухгалтер с моими грехами... Вдруг вспомнила - мама дорогая, четвертак в носке неистраченный!26.

Сознание обеих женщин повторяет известные (затертые) языковые штампы, стереотипы. Не случайно потерявшая сына мать произнося фразы, употребляемые в привычном контексте соболезнования по случаю смерти, сама убеждается в том, что они лишь имитируют потребность или желание коммуникации.

Женщина. ...Говорят — „тяжелое горе”. Когда люди говорят эти два слова, они даже не понимают, что это... Говорят — время лечит. Все притирается, родные лица бледнеют, память теряет цвет, голоса, дом привыкает к пустоте, возвращаются старые привычки... Живут же люди. Живы и счастливы и даже не знают об этом. Смерть только в кино и видят... ${ }^{27}$
23 Там же.
24 Там же.
25 Там же.
26 Там же.
27 Там же.

Slavica Wratislaviensia 167, 2018

(C) for this edition by CNS 
Набор слов-формул помогает персонажам даже провести репетицию перехода души от жизни к смерти, прохождения известного всем туннеля. Поэтому реальную смерть сожителя Старуха также интерпретирует в категориях симуляции: „Старуха (смотрит на старика). Помер... В туннель ушел" 28 . Затем она же переносит опыт переселения душ, навязанный ей пришедшей женщиной, на воображаемую ситуацию переселение души этого старика в муху. Язык должен помочь ей „исправить” некоторую нелепость, абсурдность ситуации, и она поправляет себя: „И летать, поди умеешь? Мух...”29. Язык (в данном случае в связи с отсутствием эквивалента в мужском роде) явно „сопротивляется” воле не очень осведомленной в восточных практиках старухи, и она, как в трансе, повторяет, ошибаясь, слово „сансара”.

Старуха (как заклинание). Сансара... Сансара... Сансара... Прямо... Налево... ${ }^{30}$

Можно отметить, ссылаясь на работу Жоржа Бодрийяра, что языковые симулякры в проанализированных пьесах О. Богаева сами вовлекают читателя в игру смыслов, правила которой до конца не определены, а речевые высказывания участвуют в установлении этих правил ${ }^{31}$. Привычный (экзистенциональный, бытовой, психологический) смысл явления смерти (умирания) в поэтике текста приобретает литературные, культурно-психологические контексты прошлого коллективного опыта, сохранившегося в сфере бессознательного и актуализированные в речи персонажей. В связи с этим в пьесах О. Богаева почти утрачивается прямая референция понятия „смерть”, слово и его значения находятся в неустойчивых отношениях семантической трансгрессии.

\section{Библиография}

Батай Ж., Внутренний опыт, пер. С. Фокин, Санкт-Петербуг 1998.

Бодрийяр Ж., Пароли. От фрагмента к фрагменту, пер. Н. Суслов, Екатеринбург 2016.

Бодрийяр Ж., Символический обмен и смерть, пер. С. Н. Зенкин, Москва 2000.

Богаев О., Пьеса - это модель жизни, отрезок бесконечности, беседу ведет Светлана Новикова, „Современная драматургия” 2013, № 4.

Богаев О., Русская народная почта: 13 комедий, сост. В. Э. Исхаков, Екатеринбург 2012, http://bogaev.narod.ru [дата обращения: 11.08.2017].

Васильева С., Пьесы Олега Богаева и проблемы современного драматургического языка, „Вестник Волгоградского государственного университета” 2013, серия 8, вып. 12, „Литературоведение. Журналистика”, https://cyberleninka.ru/article/n/piesy-olega-bogaeva-iproblemy-sovremennogo-dramaturgicheskogo-yazyka [дата обращения: 12.08.2017].
28 Там же.
29 Там же.
30 Там же.
${ }^{31}$ См., напр.: Ж. Батай, Внутренний опыт, пер. С. Фокин, Санкт-Петербуг 1998. 
Делез Ж., О смерти человека и о сверхчеловеке, пер. Н. Архипов, http://www.twirpx.com/ file/1890180/ [дата обращения: 3.09.2017].

Делез Ж., Пять тезисов о психоанализе, пер. Н. Архипов, Москва 2010.

Липовецкий М., Паралогии. Трансформации (пост)модернистского дискурса в русской культуре 1920-2000 годов, Москва 2008.

Пархоменко Е., Современный язык как симулякр „Дома бытия”, „Историческая и социально-образовательная мысль” 2013, № 5 (21), https://cyberleninka.ru/article/n/sovremennyyyazyk-kak-simulyakr-doma-bytiya [дата обращения: 18.08.17].

\section{Death in the simulative space of the hyperreality of modern Russian drama (on the example of Oleg Bogayev's plays)}

\section{Summary}

The image of the death's simulacrum is a product of character's speech in many comedy plays by the Russian playwright from Ekaterinburg - Oleg Bogayev, among them: Russian folk post, Dead Ears. The newest history of a toilet paper and others. In the poetics of O. Bogaev's texts, the space of hyperreality is formed and the images of life and death function as simulacra and reminiscence of the mental stereotypes of the post-Soviet era. Analysis of the use of simulacra of death in a number of Bogayev plays allows us to find authorial irony over the processes of appearance of these simulacra in the speech, and over the processes of their involvement in the universal play of senses. The abyssal situation of the repetition of the transition from life to death, repeatedly duplicated, cause action in the comedies, the gap between the word and its meaning. Language becomes, in fact, a means of simulating discourse, and, therefore, causes the illusion of communication. The context of death (dying) acquires a literary, cultural and psychological contexts of the last collective experience. That becomes a cause of the loss of the direct sense of the term, the word and its meaning lies in the relationship of semantic transgression.

Keywords: simulacrum, transgression, absurdity, hyperreality, comedy

\section{Смерть у симулятивному просторі гіперреальності сучасної російської драми (на прикладі п’єс Олега Богаєва)}

\section{Резюме}

Образ-симулякр смерті є породженням мовлення персонажів багатьох комедій сучасного російського драматурга з Єкатеринбургу Олега Богаєва. Серед них: Російська народна пошта, Мертві вуха. Новітня історія туалетного паперу та інші. В поетиці текстів Богаєва формується простір гіперреальності, образи „життя і смерті” функціонують як симулякри, що нагадують ментальні стереотипи пострадянської доби. Аналіз того, як використовуються симулякри смерті в ряді п’єс Богаєва, дозволяє виявити авторську іронію щодо процесів появи в мовленні цих симулякрів, щодо процесів їх втягування до універсальної гри смислами. 
Абсурдна ситуація повторення переходу від життя до смерті, багаторазово тиражована, організує дію в комедіях, тим самим виявляється дистанція між словом та його значенням. Мова стає, по суті, засобом симуляції дискурса, отже, викликає ілюзію комунікації. Побутовий контекст смерті (вмирання) набуває літературні, культурно-психологічні контексти минулого колективного досвіду. У зв'язку з цим втрачається пряме значення цього поняття, слово та його значення знаходяться у відношеннях семантичної трансгресії.

Ключові слова: симулякр, трансгресія, абсурд, гіперреальність, комедія 